\title{
Re-examination of the prevalence of Aphanomyces astaci in North American crayfish populations in Central Europe by TaqMan MGB real-time PCR
}

\author{
Eva Kozubíková $^{1, *}$, Trude Vrålstad ${ }^{2,3}$, Lenka Filipováa ${ }^{1,4}$, Adam Petrusek ${ }^{1}$ \\ ${ }^{1}$ Department of Ecology, Faculty of Science, Charles University in Prague, 12844 Prague 2, Czech Republic \\ ${ }^{2}$ Section of Mycology, Norwegian Veterinary Institute, 0106 Oslo, Norway \\ ${ }^{3}$ Microbial Evolution Research Group (MERG), Department of Biology, University of Oslo, 0316 Oslo, Norway \\ ${ }^{4}$ Laboratoire Ecologie, Evolution, Symbiose, UMR CNRS 6556, Université de Poitiers, 86022 Poitiers Cedex, France
}

\begin{abstract}
We applied quantitative TaqMan minor groove binder real-time polymerase chain reaction (PCR) on DNA isolates from soft abdominal cuticle of 460 North American crayfish Orconectes limosus and Pacifastacus leniusculus, previously tested for Aphanomyces astaci presence by conventional semi-nested PCR. Both approaches target the internal transcribed spacers of the pathogen nuclear ribosomal DNA, but apply different specific sequence motifs and technologies. The real-time PCR approach seems to provide higher sensitivity; the number of crayfish that tested positive increased from 23 to $32 \%$, and 10 additional crayfish populations were indicated as hosting the disease agent. However, the vast majority of newly recorded positives contained very low agent levels, from 5 to 50 PCR-forming units. An isolate producing a false positive result by the semi-nested PCR (apparently undescribed Aphanomyces related to A. astaci) remained negative using the real-time PCR. The present study shows that previous results based on the seminested PCR were not substantially influenced by false positives but might have suffered from some false negatives at low agent levels. Combining alternative methods may therefore provide more reliable conclusions on the pathogen's presence. Further, we found positive correlation between the prevalence of infection carriers in American crayfish populations and the average amounts of $A$. astaci DNA detected in infected local crayfish individuals.
\end{abstract}

KEY WORDS: Crayfish plague - Aphanomyces astaci $\cdot$ Pacifastacus leniusculus Orconectes limosus $\cdot$ Semi-nested PCR $\cdot$ Real-time PCR $\cdot$ Pathogen detection $\cdot$ Agent level

Resale or republication not permitted without written consent of the publisher

\section{INTRODUCTION}

The crayfish plague, i.e. mass mortalities of indigenous European crayfish caused by the oomycete Aphanomyces astaci (Saprolegniaceae), has serious conservational as well as economical consequences (Holdich et al. 2009) and requires fast and reliable diagnostics. Several alternative PCR-based assays for detection of the crayfish plague pathogen have been described (Oidtmann et al. 2004, 2006, Hochwimmer et al. 2009, Vrålstad et al. 2009). The first molecular method for A. astaci detection from clinical samples (based on internal transcribed spacer [ITS] in the nuclear ribosomal DNA; Oidtmann et al. 2004) considerably sped up and improved the reliability of parasite diagnostics. However, the method provided insufficient specificity against the closely related $A$. frigidophilus and $A$. invadans 
(Oidtmann et al. 2006), the first of which was isolated from crayfish as well (Ballesteros et al. 2006).

Therefore, Oidtmann et al. (2006) improved the assay by developing a new forward PCR primer that discriminated against these closely related species. For detection of the agent in North American (hereafter 'American') carrier species (including spinycheek crayfish Orconectes limosus and signal crayfish Pacifastacus leniusculus) 2 PCR protocols (one single-round and one semi-nested PCR) were established; these were sensitive enough to detect Aphanomyces astaci in symptom-free carrier crayfish. Both protocols reliably detected the crayfish plague pathogen, but the semi-nested PCR also reacted to extremely high concentrations of $A$. frigidophilus and A. invadans DNA. For this reason, Oidtmann et al. (2006) recommended the single-round PCR (not sensitive to the above-mentioned species) combined with sequencing for confirmation of $A$. astaci detection (OIE 2010). The product of the single-round PCR is suitable for distinguishing A. astaci from other oomycetes, as the sequence of the resulting ITS fragment is nearly invariable in all known $A$. astaci strains, but clearly different even from the most related known species (Diéguez-Uribeondo et al. 2009, Takuma et al. 2010, Makkonen et al. 2011). Sequencing of PCR products after single-round PCR has so far resulted in only one discovery of a false positive result (Diéguez-Uribeondo et al. 2009, Kozubíková et al. 2009), demonstrating the amplification of DNA from an hitherto unknown Aphanomyces lineage closely related to A. astaci (GenBank acc. no. FM955258) from a signal crayfish. However, this oomycete strain has not been isolated to a laboratory culture, preventing further studies and a formal description. The single-round assay according to Oidtmann et al. (2006) thus remains a very reliable method for the detection of $A$. astaci, very rare errors of which may be uncovered with sequencing, and is officially recommended by the World Organisation for Animal Health (OIE 2010).

An alternative protocol using quantitative TaqMan real-time PCR (Vrålstad et al. 2009) targets a variable part of the ITS1 region specific to Aphanomyces astaci using 2 specific primers and 1 specific TaqMan minor groove binder (MGB) probe. This probe provides higher stringency, and consequently increased specificity, than conventional primers (Vrålstad et al. 2009). Additionally, the real-time PCR approach provides lower risk of laboratory-induced contamination (there is no further manipulation of PCR products after the reaction), increased sensitivity of agent detection, and quantitative results. However, a dis- advantage of the real-time PCR assay is that its PCR product is not suitable for sequencing; thus, confirmation of the identity of the amplified fragment is not possible without conventional PCR. Simultaneously, another real-time PCR assay based on the detection of the gene for endochitinase was developed (Hochwimmer et al. 2009).

All molecular methods mentioned above have been tested against the DNA of various oomycete cultures, but published tests of DNA samples isolated directly from crayfish tissues are limited. These methods have already been used several times to answer questions concerning the distribution and prevalence of Aphanomyces astaci in invasive American crayfish populations in Europe (e.g. Schulz et al. 2006, Aquiloni et al. 2011, Skov et al. 2011); however, in most cases, only a few populations were analysed. The only published extensive study on the prevalence of $A$. astaci in American crayfish populations on a national scale (Kozubíková et al. 2009) was based on the semi-nested PCR by Oidtmann et al. (2006). Since Oidtmann et al. (2006) recommended using a single-round PCR protocol combined with sequencing, we also later applied this method to samples that tested positive in the semi-nested PCR; $80 \%$ of those samples showed positive results in the single-round PCR, suggesting that the semi-nested PCR was more sensitive (E. Kozubíková unpubl. data). However, alternative explanations of this observation could be that some proportion of samples positive in the semi-nested PCR were actually false positives, or that the DNA isolates became degraded by long-term storage (Oidtmann et al. 2006). To rule out the possibility that the semi-nested PCR protocol suffers from false positive results when applied to field samples, we decided to verify our previous results by an alternative method that has recently become available.

The development of specific assays for Aphanomyces astaci detection is an on-going process, because our knowledge about the diversity of related species possibly cross-reacting with the existing methods is still deficient. A combination of available methods may therefore improve the reliability of results. In the present study, we re-examined previously analysed samples originating from 3 Central European countries (Czech Republic, Hungary, and Slovakia) by quantitative TaqMan-MGB real-time PCR (Vrålstad et al. 2009) in order to (1) evaluate whether the previous results from the semi-nested PCR have been significantly influenced by false positives, (2) test whether the use of a different ITSbased detection method substantially influences the 
general patterns of known distribution of $A$. astaci in invasive crayfish populations, and (3) obtain semiquantitative data on the level of agent DNA in samples for comparison to the A. astaci prevalence in the carrier populations of American crayfish.

\section{MATERIALS AND METHODS}

\section{DNA isolates}

For the present study, we used 460 DNA isolates from soft abdominal cuticles of spiny-cheek crayfish Orconectes limosus (307 samples) and signal crayfish Pacifastacus leniusculus (153 samples). The crayfish came from 25 populations in the Czech Republic, 3 in Hungary and 1 in Slovakia. Each sample represented 1 crayfish individual. The samples were originally obtained for Kozubíková et al. (2006, 2008, 2009, 2010) and Petrusek \& Petrusková (2007) (see Table 2 for a list of localities and the number of analysed individuals). DNA was isolated using the DNeasy tissue kit (Qiagen) from soft abdominal cuticle (in individuals smaller than $5 \mathrm{~cm}$ a part of an uropod or telson was also included) as described by Kozubíková et al. (2009), and the isolates were stored for 1 to $5 \mathrm{yr}$ in $-20^{\circ} \mathrm{C}$. We also included a DNA isolate from a signal crayfish individual from the Czech Republic that tested false positive by conventional PCR methods (both the semi-nested and the single-round assays), but was proven to be a different Aphanomyces lineage by sequencing the PCR product of the singleround PCR (GenBank acc. no. FM955258; Kozubíková et al. 2009). ITS sequences were also available for 14 samples that were confirmed in that way to contain Aphanomyces astaci DNA (DiéguezUribeondo et al. 2009, Kozubíková et al. 2009). All these sequences (including those submitted to GenBank under acc. nos. FM999252 to FM999259 and FM999239) were invariable.

\section{Semi-nested PCR}

All DNA isolates were analysed for Aphanomyces astaci presence by semi-nested $\mathrm{PCR}_{\mathrm{i}} 15$ samples were specifically amplified for the purpose of the present study. Results for the remaining 445 samples were published by Kozubíková et al. (2006, 2008, 2009, 2010). All samples were processed as described by Kozubíková et al. (2009). The primers ' 42 ' and '640' (first PCR run) and '525' and '640' (second PCR run, using the product of the first PCR as a template) after Oidtmann et al. (2006) were used to amplify an A. astaci-diagnostic fragment of rDNA. Each $50 \mu \mathrm{l}$ PCR reaction contained $1.25 \mathrm{U}$ of Taq DNA polymerase, $1 \times$ Taq buffer (with $\mathrm{KCl}$ ), $1.5 \mathrm{mM} \mathrm{MgCl}_{2}$, $0.2 \mathrm{mM}$ of each dNTP (reagents from Fermentas), $0.5 \mu \mathrm{M}$ of each primer, and $10 \mu \mathrm{l}$ of template DNA. Cycling conditions followed the protocol provided by Oidtmann et al. (2006). After agarose electrophoresis, a DNA fragment identical in length to that obtained from the positive control (DNA isolate from a clean laboratory culture of $A$. astaci of the Strain M96/1, Genetic Group B from Oidtmann et al. 1999) was considered to show detection of $A$. astaci in the individual crayfish.

\section{TaqMan MGB real-time PCR}

Quantitative detection of Aphanomyces astaci by real-time PCR was performed as described by Vrålstad et al. (2009) using an A. astaci-specific pair of primers (AphAstITS-39F and AphAstITS-97R) combined with the $A$. astaci-specific MGB probe (AphAstITS-60P). The total reaction volume of $25 \mu \mathrm{l}$ contained 12.5 $\mu$ l TaqMan Universal PCR Master Mix (Applied Biosystems) with the passive reference dye ROX, $500 \mathrm{nM}$ of the forward and reverse primers, $200 \mathrm{nM}$ of the MGB probe, $1.5 \mu \mathrm{l}$ sterile milliQ water, and $5 \mu \mathrm{l}$ of template DNA. Amplification and detection were performed on the Mx3005P qPCR system (Stratagene) whereby the PCR reactions were set up in 96-well polypropylene plates sealed with $8 \times$ strip optical caps for Stratagene (Agilent Technologies). The PCR program included an initial decontamination step of $2 \mathrm{~min}$ at $50^{\circ} \mathrm{C}$ followed by $10 \mathrm{~min}$ at $95^{\circ} \mathrm{C}$ for DNA polymerase activation, uracil N-glycosylase deactivation and template DNA denaturation. Afterwards, 50 cycles of $15 \mathrm{~s}$ at $95^{\circ} \mathrm{C}$ and $60 \mathrm{~s}$ at $58^{\circ} \mathrm{C}$ were carried out. Four calibration points of a standard series of known PFU (PCR-forming units or amplifiable copies of the target DNA) content were included in each run (see Vrålstad et al. 2009). In order to avoid carry-over contamination from the standard, the 4 calibrants were added to the plate after sealing all other unknown crayfish DNA samples with the $8 \times$ strip caps. Finally, negative PCR controls were included in all runs; these remained negative in all cases.

The sample that included the DNA of the new Aphanomyces lineage related to A. astaci (FM955258; Kozubíková et al. 2009) was tested further with the TaqMan Environmental Master Mix (Applied Biosystems), which appears to work more effectively ac- 
cording to Strand et al. (2011). Two separate tests (both repeated twice) were performed: (1) under the same conditions as described above and (2) with elevated annealing and synthesis temperature using 50 cycles of $15 \mathrm{~s}$ at $95^{\circ} \mathrm{C}$ and $60 \mathrm{~s}$ at $60^{\circ} \mathrm{C}$. Only the $10 \times$ diluted sample was available for these additional tests, as the stock of the DNA isolate became limited.

\section{Quantification of real-time PCR data}

The data were analysed in the MxPro software V.4.10 (Stratagene). The calibration points were used to generate a standard curve for quantification of Aphanomyces astaci in terms of PFU in the unknown crayfish tissue samples, and corresponded to the standards 1, 3, 7, and 9 in Vrålstad et al. (2009), with estimated numbers of PFU corresponding to $3 \times 4^{10}$, $3 \times 4^{8}, 3 \times 4^{4}$, and $3 \times 4^{2}$ (Table 3 in Vrålstad et al. 2009). Each DNA isolate was tested with an undiluted and a 10-fold diluted replicate.

Absolute quantification is possible in the absence of PCR inhibition above the limit of quantification ( $L O Q=50$ PFU; Vrålstad et al. 2009). The presence or absence of real-time PCR inhibition was controlled by calculating the difference in $\mathrm{Ct}$ (cycle threshold) values $(\Delta \mathrm{Ct})$ between the undiluted and corresponding 10-fold diluted DNA replicates. In the absence of inhibition, ideal amplification efficiency and no laboratory-induced inaccuracies, the theoretical $\Delta \mathrm{Ct}$ value equals 3.32. In practice, some variation arises due to minor inaccuracies related to amplification efficiency, manual pipetting, and other stochastic factors. Here, we considered acceptable a variance level of $15 \%$, then allowing for quantification in samples where the $\Delta \mathrm{Ct}$ is $3.32 \pm 0.5$ (range $=2.82$ to 3.82 ) between the undiluted and 10-fold diluted replicates. For samples where Aphanomyces astaci could be quantified above LOQ, the final PFU-values were estimated as follows: when $\Delta \mathrm{Ct}$ was within the accepted range from 2.82 to 3.83 , the final PFU-value was calculated as the mean of the undiluted PFUvalue and the 10-fold diluted PFU-value, the latter multiplied by 10 . If $\Delta \mathrm{Ct}$ was $<2.82$ (indicating inhibition) or $>3.82$ (i.e. 10 -fold dilution out of range), the final PFU-values could not be calculated accurately, but for comparative purposes we used an estimate based on the most relevant of the 2 values obtained. In the former case, the estimated PFU was based on the 10-fold diluted DNA replicate alone (for which the effects of inhibition were expected to be eliminated or less pronounced), and, in the latter case, it was based solely on the undiluted DNA replicate.
Finally, all samples were assigned to the more comprehensible semi-quantitative categories (agent levels) suggested by Vrålstad et al. (2009). These categories and their limit values are described in Table 1.

\section{Statistical analyses}

The proportion of crayfish individuals that tested positive with the 2 methods was compared by the Chi-squared test, for all analysed individuals pooled as well as separately for the 2 crayfish species. The relationship between the prevalence of infected individuals in the crayfish populations (i.e. the likelihood that any particular crayfish in the population sample tests positive by real-time PCR) and the average amount of the pathogen DNA detected in apparently infected crayfish individuals from each population (expressed as PFU-values; log-transformed for the analysis) was analysed separately for both host crayfish species by logistic regression (using the maximum-likelihood loss function and quasi-Newton estimation method). For the calculation of the average pathogen load, we also included crayfish individuals with Agent Level A2. Although these levels of the pathogen DNA are below the limit of reliable quantification, we used the resulting low (though less accurate) PFU-values in the calculation in order to avoid an artificial increase in the estimated average load, as would be expected if the lightly infected crayfish hosts were excluded. The tests were performed in the software Statistica V.6.1 (StatSoft).

\section{RESULTS}

\section{Prevalence of Aphanomyces astaci carriers in crayfish populations: re-evaluation of previous data}

The results of the prevalence of Aphanomyces astaci in American crayfish Orconectes limosus and Pacifastacus leniusculus obtained by the semi-nested PCR and the real-time PCR are summarised in Table 2 according to crayfish species and origin. The real-time PCR approach detected the pathogen in 46 crayfish individuals that remained negative with the semi-nested PCR (Table 3, Fig. 1a). With 5 exceptions, these detections represented Agent Level A2 (Table 3). The remaining 5 semi-nested PCR negative results were detected at Agent Level A3, but the PFU-values were $<100$ in all cases. 
Table 1. Semi-quantitative categories of agent levels of Aphanomyces astaci in a test sample based on the number of PCRforming units (PFU) detected (after Vrålstad et al. 2009). Agent Level A1 (traces below the limit of detection) may indicate a minute or very early sign of infection, but could also represent false positives in terms of PCR artifacts or minimal carry-over contamination from another sample; such a result is consequently not taken as sufficient evidence for the pathogen's detection. PFU refers to amplifiable DNA copies of the analyte (the $57 \mathrm{bp}$ DNA-sequence motif of $A$. astaci) in a PCR reaction tube. $\mathrm{Ct}$ (cycle threshold) values are based on the study by Vrålstad et al. (2009). Differences in the signal acquisition systems will result in minor differences in measured Ct-values with different thermal cyclers; values listed here are thus only guiding and not absolute. A molecular assay must always be validated in-house and calibrated based on the assigned concentrations of the standards (calibration material) prior to application in diagnostics on a new thermal cycler or in a new laboratory. LOD: limit of detection (defined as $95 \%$ probability of detection: 5 PFU); LOQ: limit of quantification (50 PFU); obs: observed values

\begin{tabular}{|c|c|c|c|c|}
\hline Agent level & PFU in sample & Expected Ct & Result & Interpretation \\
\hline $\mathrm{A} 0$ & 0 or below Ct cut-off value & $\begin{array}{l}\text { Undetermined or } \\
\mathrm{Ct}>41\end{array}$ & Not detected & Negative \\
\hline A1 & $\begin{array}{l}\text { Detected below LOD } \\
\left(\mathrm{PFU}_{\text {obs }}<5 \text { PFU) }\right.\end{array}$ & $41 \geq \mathrm{Ct}_{\mathrm{obs}}>39$ & $\begin{array}{l}\text { Detected below } \\
\text { LOD }\end{array}$ & Trace amounts, not a reliable detection \\
\hline A2 & $\begin{array}{l}\mathrm{LOD} \leq \mathrm{PFU}_{\mathrm{obs}}<\mathrm{LOQ} \\
=50 \mathrm{PFU}\end{array}$ & $39 \geq \mathrm{Ct}_{\mathrm{obs}}>34.7$ & Detected & $\begin{array}{l}\text { Very low levels of } A \text {. astaci DNA in } \\
\text { sample (below LOQ) }\end{array}$ \\
\hline A3 & $\mathrm{LOQ} \leq \mathrm{PFU}_{\mathrm{obs}}<10^{3} \mathrm{PFU}$ & $34.7 \geq \mathrm{Ct}_{\mathrm{obs}}>30.0$ & Detected & Low levels of $A$. astaci DNA in sample \\
\hline A4 & $10^{3} \mathrm{PFU} \leq \mathrm{PFU}_{\mathrm{obs}}<10^{4} \mathrm{PFU}$ & $30.0 \geq \mathrm{Ct}_{\mathrm{obs}}>26.2$ & Detected & $\begin{array}{l}\text { Moderate levels of A. astaci DNA in } \\
\text { sample }\end{array}$ \\
\hline A5 & $10^{4} \mathrm{PFU} \leq \mathrm{PFU}_{\mathrm{obs}}<10^{5} \mathrm{PFU}$ & $26.2 \geq \mathrm{Ct}_{\mathrm{obs}}>22.6$ & Detected & High levels of $A$. astaci DNA in sample \\
\hline A6 & $10^{5} \mathrm{PFU} \leq \mathrm{PFU}_{\mathrm{obs}}<10^{6} \mathrm{PFU}$ & $22.6 \geq \mathrm{Ct}_{\mathrm{obs}}>18.5$ & Detected & $\begin{array}{l}\text { Very high levels of } A \text {. astaci DNA in } \\
\text { sample }\end{array}$ \\
\hline A7 & $10^{6} \mathrm{PFU} \leq \mathrm{PFU}_{\mathrm{obs}}$ & $\mathrm{Ct}_{\mathrm{obs}} \leq 18.5$ & Detected & $\begin{array}{l}\text { Exceptionally high levels of } A \text {. astaci } \\
\text { DNA in sample }\end{array}$ \\
\hline
\end{tabular}

The percentage of samples testing positive (excluding the 1 known false positive reported by Kozubíková et al. 2009) significantly increased when the real-time PCR rather than the semi-nested PCR was used $\left(\chi^{2}=8.7, p=0.003\right)$ : from 23 to $32 \%$ (Fig. $1 \mathrm{a}$, Table 2). Interestingly, the majority of new detections were from signal crayfish, where the prevalence of Aphanomyces astaci increased from $3 \%$ of all analysed individuals to $21 \%$. This increase was highly significant $\left(\chi^{2}=22.4, p<0.0001\right)$, which was not the case for spiny-cheek crayfish. In the latter species, the proportion of individuals that tested positive increased from 34 to $38 \%\left(\chi^{2}=1.2, p=0.27\right)$.

Overall, the number of crayfish populations with 1 or more individual with a positive test among the examined individuals increased from 14 with the semi-nested PCR to 24 with the real-time PCR (Table 2). For the remaining 5 of the 29 tested populations where no infected individual was detected, only a low number of individuals were tested (11 from a Köszeg boating pond in Hungary, otherwise 1 to 3 individuals). These negative results are therefore of no conclusive value. Two individuals with very low levels of the target DNA (Agent Level A2) were discovered in a population of signal crayfish that had coexisted with the native European species Astacus astacus for at least $10 \mathrm{yr}$.

\section{The semi-nested PCR versus the quantitative TaqMan real-time PCR}

The real-time PCR detected the target DNA in a considerably higher number of samples than did the semi-nested PCR (Table 3, Fig. 1a). Although the latter method was less sensitive, it worked with $100 \%$ reliability in samples containing $>100$ PFU per reaction quantified with the real-time PCR. The efficiency of the semi-nested PCR compared to the realtime PCR was $92 \%$ in the category A3, but only $41 \%$ in the category A2 (Table 3).

Table 3 shows that all but 7 samples (i.e. 94\%) that tested positive for Aphanomyces astaci using the semi-nested PCR also produced a positive result above the limit of detection (LOD) with the realtime PCR. The 7 samples not confirmed as positive with the real-time PCR included 5 samples in which trace amounts of the target DNA were detected below LOD (Agent Level A1). In the remaining 2 DNA isolates, no $\mathrm{Ct}$ or $\mathrm{Ct}>41$ (the cut-off value, see Table 1) was detected (Agent Level A0). One of these was an already known case of false positive detection, an isolate containing the DNA of a putative undescribed Aphanomyces sp. closely related to A. astaci from signal crayfish from the Czech Republic (GenBank acc. no. FM955258; Kozubíková 
Table 2. Detailed results of Aphanomyces astaci prevalence in North American crayfish Orconectes limosus and Pacifastacus leniusculus populations obtained by semi-nested PCR and real-time PCR assays. Semi-nested PCR results were published by Kozubíková et al. (2006, 2008, 2009, 2010). Results for samples originating in the Czech Republic are summarised separately to allow direct comparison with Kozubíková et al. (2009). A5 to A2: agent levels (see Table 1)

\begin{tabular}{|c|c|c|c|c|c|c|c|c|c|}
\hline \multirow[t]{2}{*}{ Crayfish sampling locality } & \multirow{2}{*}{$\begin{array}{c}\text { Animals } \\
\text { tested }\end{array}$} & \multicolumn{2}{|c|}{ Semi-nested PCR } & \multirow{2}{*}{ A5 } & \multicolumn{5}{|c|}{ Real-time PCR } \\
\hline & & No. positive & $\%$ & & $\mathrm{~A} 4$ & A3 & A2 & No. positive & $\%$ \\
\hline \multicolumn{10}{|l|}{ Orconectes limosus } \\
\hline Jickovický Brook (49²6’ N, 14²13' E) & 13 & 13 & 100 & & 1 & 12 & & 13 & 100 \\
\hline Prudník Brook $\left(50^{\circ} 17^{\prime} \mathrm{N}, 17^{\circ} 43^{\prime} \mathrm{E}\right)$ & 11 & 11 & 100 & & 1 & 10 & & 11 & 100 \\
\hline Smečno village pond $\left(50^{\circ} 11^{\prime} \mathrm{N}, 14^{\circ} 02^{\prime} \mathrm{E}\right)$ & 40 & 39 & 98 & 1 & 10 & 21 & 7 & 39 & 98 \\
\hline Kořensko Reservoir $\left(49^{\circ} 14^{\prime} \mathrm{N}, 14^{\circ} 22^{\prime} \mathrm{E}\right)$ & 3 & 2 & 67 & & 2 & & & 2 & 67 \\
\hline Elbe River (5 different sites) ${ }^{\mathrm{a}}$ & 20 & 12 & 60 & & 1 & 5 & 6 & 12 & 60 \\
\hline Pšovka Brook $\left(50^{\circ} 23^{\prime} \mathrm{N}, 14^{\circ} 33^{\prime} \mathrm{E}\right)$ & 18 & 9 & 50 & & & 6 & 5 & 11 & 61 \\
\hline Zlatá stoka Brook $\left(49^{\circ} 00^{\prime} \mathrm{N}, 14^{\circ} 46^{\prime} \mathrm{E}\right)^{\mathrm{a}}$ & 19 & 8 & 42 & & & & 5 & 5 & 26 \\
\hline Hracholusky Reservoir $\left(49^{\circ} 47^{\prime} N, 13^{\circ} 07^{\prime} E\right)^{a}$ & 20 & 4 & 20 & & & & 3 & 3 & 15 \\
\hline Malše River $\left(48^{\circ} 57^{\prime} \mathrm{N}, 14^{\circ} 28^{\prime} \mathrm{E}\right)$ & 12 & 1 & 8 & & & 2 & 1 & 3 & 25 \\
\hline Proboštská jezera Lake $\left(50^{\circ} 12^{\prime} \mathrm{N}, 14^{\circ} 39^{\prime} \mathrm{E}\right)$ & 17 & 1 & 6 & & & 1 & 5 & 6 & 35 \\
\hline Klíčov flooded quarry $\left(49^{\circ} 24^{\prime} N, 12^{\circ} 57^{\prime} \mathrm{E}\right)^{\mathrm{a}}$ & 40 & 1 & 3 & & & & 1 & 1 & 3 \\
\hline Kojetice flooded sandpit $\left(50^{\circ} 14^{\prime} \mathrm{N}, 14^{\circ} 31^{\prime} \mathrm{E}\right)$ & 20 & & 0 & & & & 3 & 3 & 15 \\
\hline Cítov flooded sandpit $\left(50^{\circ} 24^{\prime} \mathrm{N}, 14^{\circ} 23^{\prime} \mathrm{E}\right)$ & 10 & & 0 & & & & 2 & 2 & 20 \\
\hline Lhota flooded sandpit $\left(50^{\circ} 14^{\prime} \mathrm{N}, 14^{\circ} 40^{\prime} \mathrm{E}\right)$ & 33 & & 0 & & & & 2 & 2 & 6 \\
\hline Kamenička Brook $\left(50^{\circ} 44^{\prime} \mathrm{N}, 14^{\circ} 11^{\prime} \mathrm{E}\right)$ & 1 & & 0 & & & & 1 & 1 & 100 \\
\hline Barbora flooded coal mine $\left(50^{\circ} 38^{\prime} \mathrm{N}, 13^{\circ} 45^{\prime} \mathrm{E}\right)$ & 2 & & 0 & & & & & & 0 \\
\hline Cidlina River $\left(50^{\circ} 07^{\prime} \mathrm{N}, 15^{\circ} 10^{\prime} \mathrm{E}\right)$ & 3 & & 0 & & & & & & 0 \\
\hline Račice flooded sandpit $\left(50^{\circ} 26^{\prime} \mathrm{N}, 14^{\circ} 19^{\prime} \mathrm{E}\right)$ & 2 & & 0 & & & & & & 0 \\
\hline Vltava River $\left(50^{\circ} 08^{\prime} \mathrm{N}, 14^{\circ} 23^{\prime} \mathrm{E}\right)$ & 1 & & 0 & & & & & & 0 \\
\hline Summary-Czech populations & 285 & 101 & 35 & & & & & 114 & 40 \\
\hline Danube, Hungary $\left(46^{\circ} 21^{\prime} \mathrm{N}, 18^{\circ} 53^{\prime} E\right)^{\mathrm{b}}$ & 22 & 2 & 9 & & & 1 & 1 & 2 & 9 \\
\hline Summary-O. limosus & 307 & 103 & 34 & 1 & 15 & 58 & 42 & 116 & 38 \\
\hline \multicolumn{10}{|l|}{ Pacifastacus leniusculus } \\
\hline Stržek fishpond $\left(49^{\circ} 22^{\prime} \mathrm{N}, 16^{\circ} 04^{\prime} \mathrm{E}\right)$ & 20 & 1 & 5 & & & & 2 & 2 & 10 \\
\hline Ráček II fishpond $\left(49^{\circ} 39^{\prime} \mathrm{N}, 16^{\circ} 18^{\prime} \mathrm{E}\right)$ & 23 & $1^{\mathrm{c}}$ & 4 & & & & 2 & 2 & 9 \\
\hline Nad tratí fishpond $\left(49^{\circ} 22^{\prime} \mathrm{N}, 16^{\circ} 04^{\prime} \mathrm{E}\right)$ & 49 & & 0 & & & 3 & 15 & 18 & 37 \\
\hline Blanice River $\left(49^{\circ} 09^{\prime} \mathrm{N}, 14^{\circ} 10^{\prime} \mathrm{E}\right)$ & 8 & & 0 & & & & 2 & 2 & 25 \\
\hline Spustík fishpond $\left(49^{\circ} 22^{\prime} \mathrm{N}, 16^{\circ} 07^{\prime} \mathrm{E}\right)$ & 13 & & 0 & & & & 2 & 2 & 15 \\
\hline Kouba Brook $\left(49^{\circ} 19^{\prime} \mathrm{N}, 13^{\circ} 01^{\prime} \mathrm{E}\right)$ & 11 & & 0 & & & & 1 & 1 & 9 \\
\hline Summary-Czech populations & 124 & $1^{\mathrm{d}}$ & 1 & & & & & 27 & 22 \\
\hline Gyöngyös River, Hungary $\left(47^{\circ} 23^{\prime} \mathrm{N}, 16^{\circ} 32^{\prime} \mathrm{E}\right)^{\mathrm{b}}$ & )$^{\mathrm{b}} 16$ & 4 & 25 & & & 2 & 2 & 4 & 25 \\
\hline Köszeg Pond, Hungary $\left(47^{\circ} 23^{\prime} \mathrm{N}, 16^{\circ} 32^{\prime} \mathrm{E}\right)^{\mathrm{b}}$ & 11 & & 0 & & & & & & 0 \\
\hline Morava River, Slovakia $\left(48^{\circ} 24^{\prime} \mathrm{N}, 16^{\circ} 51^{\prime} \mathrm{E}\right)$ & 2 & & 0 & & & & 1 & 1 & 50 \\
\hline Summary—P. leniusculus & 153 & $5^{\mathrm{d}}$ & 3 & & & 5 & 27 & 32 & 21 \\
\hline Summary_both species & 460 & $108^{\mathrm{d}}$ & 23 & 1 & 15 & 63 & 69 & 148 & 32 \\
\hline \multicolumn{10}{|c|}{$\begin{array}{l}{ }^{a} \text { One to } 3 \text { samples from each of these populations were found to be positive with the semi-nested PCR but negative with } \\
\text { the real-time PCR (putative false positives of the semi-nested PCR) } \\
{ }^{\text {b}} \text { Real-time PCR results published by Kozubíková et al. (2010) } \\
\text { cFalse positive result of the semi-nested PCR confirmed by sequencing } \\
{ }^{\mathrm{d} F a l s e ~ p o s i t i v e ~ r e s u l t ~ f r o m ~ R a ́ c ̌ e k ~ I I ~ f i s h p o n d ~ w a s ~ n o t ~ i n c l u d e d ~ i n ~ s u m m a r y ~ v a l u e s ~ a s ~ i t ~ w a s ~ n o t ~ c o n s i d e r e d ~ p o s i t i v e ~ i n ~ t h e ~} \\
\text { study by Kozubíková et al. (2009) }\end{array}$} \\
\hline
\end{tabular}

et al. 2009). A weak signal appeared in the tests using the TaqMan Universal PCR Master Mix, but never crossed the fixed baseline $(=0.15)$. In the tests using the TaqMan Environmental Master Mix, the putative false positive was detected at $\mathrm{Ct} 42$, well below the cut-off value. Further, with elevated annealing and synthesis temperatures, the signal touched the baseline at $\mathrm{Ct} 50$ (Fig. 2).

\section{Quantitative results}

Among all samples tested in the present study, $68 \%$ were negative. A further 15\% fell within Agent Level A2 (under the LOQ), in which the undiluted DNA was detected in the A2 category, while the 10fold diluted DNA remained negative or was detected in the A1 category. The remaining $17 \%$ of the sam- 
Table 3. Efficiency of the semi-nested PCR assay compared to the real-time PCR for detection of Aphanomyces astaci. Several cases of A. astaci detections were confirmed by sequencing at each agent level (see Table 1). Sequence results are from Kozubíková et al. (2009); accession numbers of those submitted to GenBank are FM999239 and FM999252 to FM999259, the 5 remaining sequences were invariable. Sequenced PCR products represented various host populations, and were not chosen according to agent level. LOQ: limit of quantification (50 PFU); LOD: limit of detection (defined as $95 \%$ probability of detection; 5 PFU); A0: all samples with no detection or with detection below the cycle threshold cut-off value of 41

\begin{tabular}{|lcccc|}
\hline Agent level & $\begin{array}{c}\text { Real-time PCR } \\
\text { (no. in each } \\
\text { category) }\end{array}$ & $\begin{array}{c}\text { Semi-nested } \\
\text { PCR (no. } \\
\text { positive) }\end{array}$ & $\begin{array}{c}\text { No. of samples } \\
\text { sequenced as } \\
\text { A. astaci }\end{array}$ \\
\hline A5 & 1 & 1 & 100 & \\
A4 & 15 & 15 & 100 & 6 \\
A3 & 63 & 58 & 92 & 4 \\
A2 (detection & 69 & 28 & 41 & 4 \\
below LOQ) & & 5 & & \\
A1 (detection & 98 & 2 & & \\
below LOD) & & & & \\
A0 (negative) & 214 & & & \\
\hline
\end{tabular}

bition (i.e. the observed $\Delta \mathrm{Ct}$ was slightly smaller than the values accepted for quantification purposes). Finally, in $28 \%$ of these samples, the 10-fold dilution was slightly out of range (i.e. the observed $\Delta \mathrm{Ct}$ was slightly larger than the values accepted for quantification). In the majority of these cases, the 10fold diluted DNA replicate was diluted out of the quantitative range, and the undiluted replicate was detected in Agent Level A3 just above the LOQ (Table 4, Table A1).

The distribution of the real-time PCR results among the semi-quantitative agent levels for spiny-cheek crayfish and signal crayfish is summarised in Fig. 1b. For both species, almost $50 \%$ were negative, and 16 to $32 \%$ of the samples (for spiny-cheek crayfish and signal crayfish, respectively) fell into the A1 category (trace DNA amount, detection below LOD), which should not be regarded as reliable positives (Vrålstad et al. 2009). The remaining 38 and $21 \%$ of the samples (spiny-cheek crayfish and signal ples were detected above the $\mathrm{LOQ}$, and fell into Agent Levels A3 (14\%), A4 (3.3\%), and A5 (0.2\%). For these, quantitative PFU-values are listed in Table A1 in Appendix 1.

The quantitative PFU-values (based on medians with 10 and $90 \%$ percentiles) for each agent level above the LOQ are summarised in Table 4 . For $68 \%$ of these samples, the obtained $\Delta \mathrm{Ct}$ value was within the range accepted for quantification. Severe inhibition was never observed, but $3.8 \%$ of the samples detected above the LOQ showed signs of minor inhicrayfish, respectively) were regarded as reliable positives (i.e. detection above LOD). The majority of positive samples of signal crayfish fell within Agent Level A2, while the majority of positive spiny-cheek crayfish samples fell within Agent Level A3. A small number of spiny-cheek crayfish fell within the A4 and A5 agent levels, while none of the analysed signal crayfish samples contained higher levels of agent DNA than A3 (Fig. 1b). Out of 14 samples from which the presence of Aphanomyces astaci DNA was confirmed by sequencing, 4 contained very low levels of
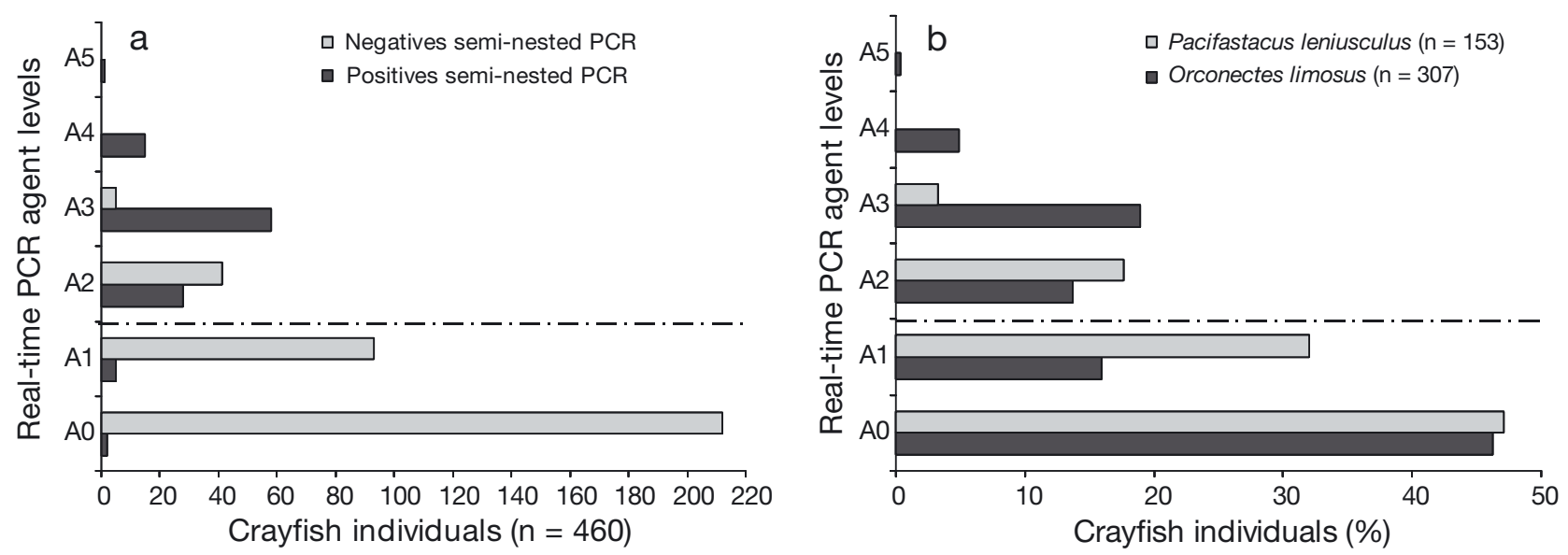

Fig. 1. (a) Numbers of positive and negative semi-nested PCR results compared to the corresponding real-time PCR results in terms of agent levels (defined in Table 1). (b) Summary of the real-time PCR results for Orconectes limosus and Pacifastacus leniusculus. The agent levels above the horizontal dashed line (A2 to A5) are considered to show reliable detection of Aphanomyces astaci 
agent DNA (A2), while the remaining 10 samples fell within the categories A3 and A4 (Table 3).

The prevalence of Aphanomyces astaci-positive crayfish individuals per population positively corre- lated with the average levels of the parasite DNA detected in crayfish from each population (Fig. 3). Logistic regressions were significant for both host crayfish species (spiny-cheek crayfish: odds ratio per
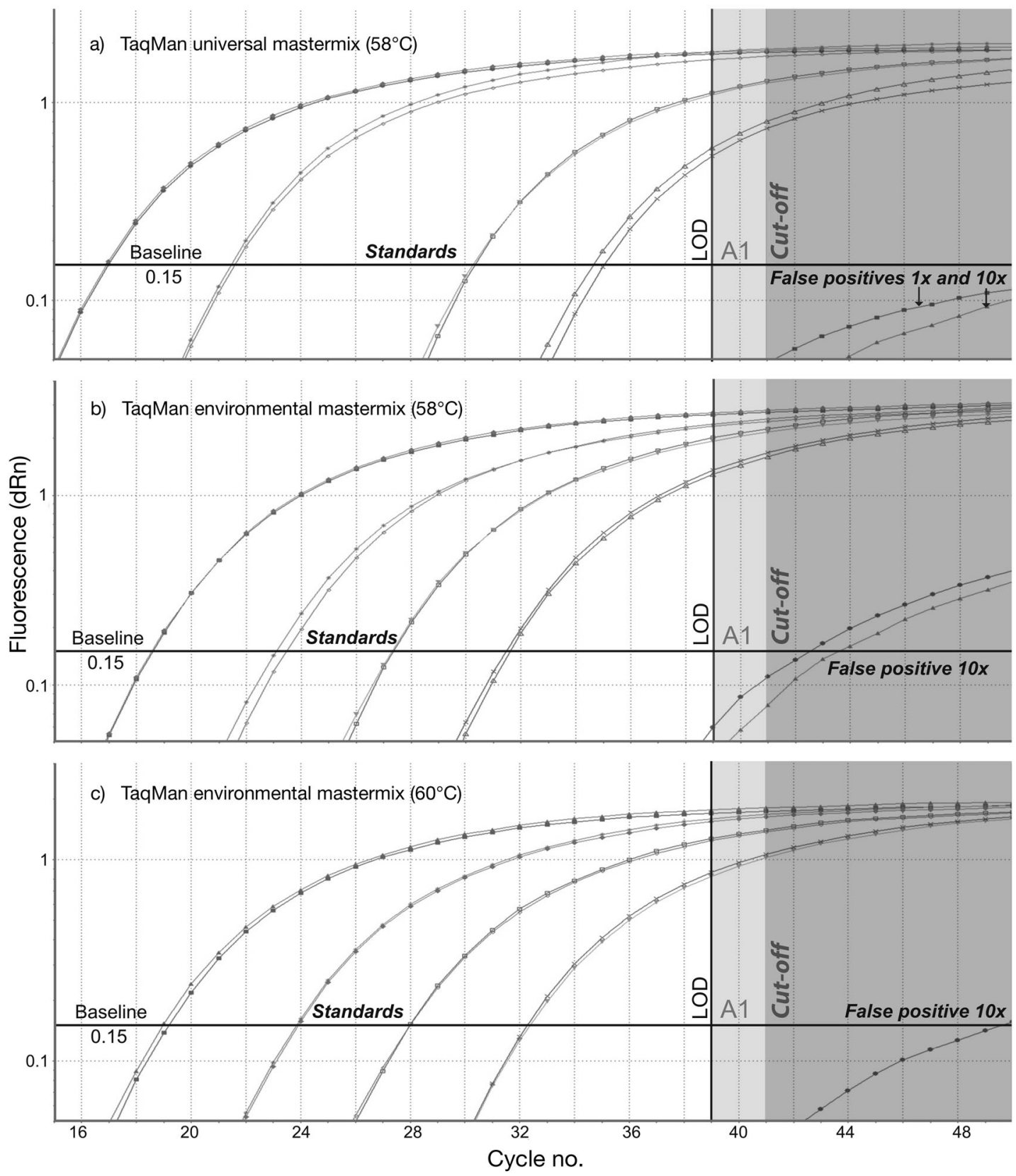

Fig. 2. Real-time PCR analyses of the sample containing DNA of Aphanomyces sp., which resulted in a false positive detection of the crayfish plague pathogen by conventional PCR (Genbank acc. no. FM955258; Kozubíková et al. 2009), performed with (a) TaqMan Universal PCR Master Mix and annealing and synthesis at $58^{\circ} \mathrm{C}$, or $(\mathrm{b}, \mathrm{c})$ TaqMan® Environmental Master Mix and annealing and synthesis at (b) $58^{\circ} \mathrm{C}$ or (c) $60^{\circ} \mathrm{C}$. The baseline was fixed at 0.15 . The vertical black lines denote the limit of detection (LOD) of the real-time PCR assay (Ct 39). The dark grey area indicates the cut off area (Ct $\geq 41$ ) in which any positive signals are excluded. The detection area for Agent Level A1 is indicated in light grey. The originally concentrated sample $(1 \times)$ was no longer available for (b) and (c), for which only the 10-fold diluted original DNA was used. The standards in (a) and (b,c) correspond to standard numbers 1, 3, 7, and 9, and 2, 4, 6, and 8, respectively, from Vrålstad et al. (2009). The false positive DNA yields very weak signals that do not cross the baseline in (a), cross the baseline after Ct 42 in (b), and cross the baseline 
Table 4. Summary of quantitative samples. DNA samples detected above the limit of quantification (LOQ $=50 \mathrm{PFU}$ ). Samples in Agent Level A3 accounted for the majority $(81 \%)$ of quantifiable samples (QS). PFU-values are based on median values with 10 and $90 \%$ percentiles in parentheses. Acceptable quantification (AQ): the difference in cycle threshold values $(\Delta \mathrm{Ct})$ between the 10 fold diluted and the undiluted DNA replicates within the range of $3.32 \pm 0.5$. Non-acceptable quantification (NQ): a $\Delta \mathrm{Ct}>3.82$ indicates that the 10 -fold diluted DNA replicate is out of range (OR). A $\Delta \mathrm{Ct}<2.82$ indicates minor inhibition (MI) in the undiluted DNA replicate. Background data are provided in Table A1

\begin{tabular}{|lcccccc|}
\hline $\begin{array}{l}\text { Agent } \\
\text { level }\end{array}$ & $\begin{array}{c}\text { Total QS } \\
(\%)\end{array}$ & $\begin{array}{c}\text { Median } \\
\text { PFU }\end{array}$ & $\begin{array}{c}\text { Mean } \\
\Delta \mathrm{Ct}\end{array}$ & $\begin{array}{c}\text { AQ } \\
(\%)\end{array}$ & $\begin{array}{c}\text { NQ } \\
\text { OR (\%) }\end{array}$ & MI (\%) \\
\hline A5 & 1.3 & 45695 & 3.47 & 100 & 0 & 0 \\
A4 & 17.7 & $2000(1259,5815)$ & $3.62( \pm 0.20)$ & 86.7 & 13.3 & 0 \\
A3 & 81 & $160(69,530)$ & $3.76( \pm 0.78)$ & 63.5 & 31.7 & 4.8 \\
Overall & 100 & & & 68.4 & 27.9 & 3.8 \\
\hline
\end{tabular}

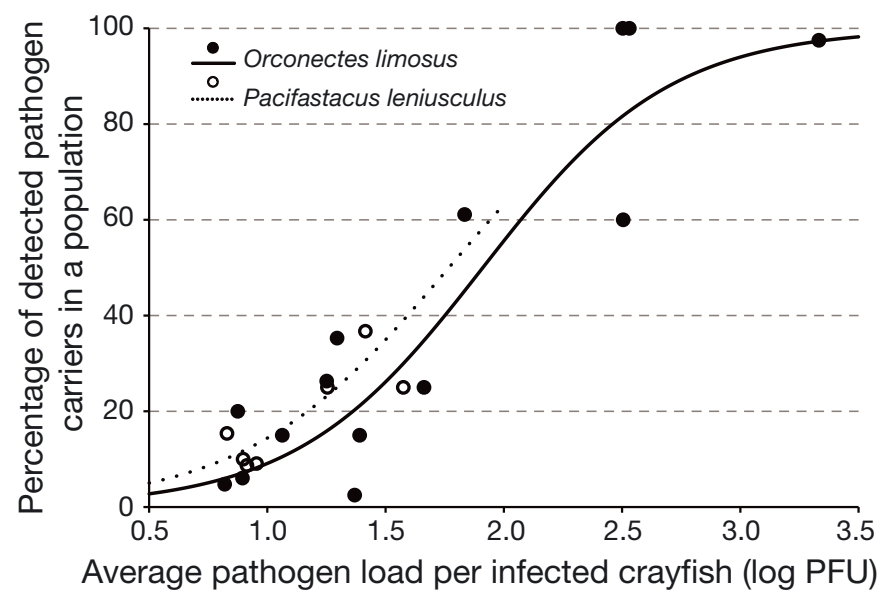

Fig. 3. Relationship between pathogen prevalence in the population and average agent level in infected individuals. The prevalence is estimated as a proportion of individuals testing positive for the presence of Aphanomyces astaci, the pathogen load (expressed as PFU detected in a real-time PCR reaction) is log-transformed for the analysis. Curves show the values predicted by logistic regressions: Orconectes limosus: $y=\mathrm{e}^{-4.83+2.53 x} /\left(1+\mathrm{e}^{-4.83+2.53 x}\right)$; Pacifastacus leniusculus: $y=\mathrm{e}^{-4.10+2.32 \mathrm{x}} /\left(1+\mathrm{e}^{-4.10+2.32 x}\right)$

10-fold increase in PFU: 12.51, $\chi^{2}=160.8, \mathrm{df}=1, \mathrm{p}<$ $10^{-7}$; signal crayfish: odds ratio: $10.19, \chi^{2}=9.04, \mathrm{df}=$ $1, \mathrm{p}=0.0026$ ). All samples containing $>10^{3} \mathrm{PFU}$ per PCR reaction (Agent Levels A4 and A5) were found in populations with a high prevalence of infected crayfish individuals (60 to $100 \%$; Table 2 ).

\section{DISCUSSION}

In the present study, the results of the semi-nested PCR (Kozubíková et al. 2009, 2010) were largely confirmed by real-time PCR in terms of positive carrier status and did not appear to be notably influenced by false positive results. In contrast, the real-time PCR assay significantly increased the overall number of crayfish that tested positive, suggesting that this method provides higher sensitivity. Using Aphanomyces astaci pure culture material and zoospores, Tuffs \& Oidtmann (2011) demonstrated that the ITS real-time PCR assay is 10- and 100 -fold more sensitive than conventional PCR (Oidtmann et al. 2006) and chitinase real-time PCR (Hochwimmer et al. 2009) assays, respectively. However, a comparative study of the ITSand chitinase-based methods (Hochwimmer et al. 2009) used on crayfish samples is still lacking and might be useful.

Improvement of the molecular detection methods of Aphanomyces astaci is a continuous process. The recently discovered A. salsuginosus (Takuma et al. 2010) isolated from ice fish Salangichthys microdon in Asia is hitherto the closest described relative of $A$. astaci based on the ITS-sequence data and also resembles the Aphanomyces lineage (FM955258) yielding the false positive with conventional PCR methods (Fig. 4). These species, together with the assumed huge unknown diversity of oomycetes, are continuously challenging the claimed specificity of any A. astaci diagnostic methods. It is urgent to test real-time and conventional PCR methods against genuine DNA from $A$. salsuginosus. However, unlike conventional PCR assays, real-time PCR proved robust against the false positive Aphanomyces lineage, despite the high homology between this ITS sequence and the primer and probe motifs of the real-time assay (Fig. 4). Our test cannot exclude the possibility that the real-time assay could cross-react if higher concentrations of this false positive DNA were present in the reaction, but the observed robustness is probably a result of the high discriminatory ability of the MGB probe. In contrast to conventional TaqMan (hydrolysis) probes, MGB probe assays allow very little mismatch at the probing site (Yao et al. 2006). Interestingly, the observed signal delay with increased primer and probe annealing temperature indicates that an optimization of the method could further increase its robustness against false positives. These results also justify the use of cut-off values when interpreting real-time PCR results. 
AM947024 A. astaci VI03628 AY310501 A. astaci LI AY683896 A. astaci PC AY683894 A. astaci Kv1 AY310499 A. astaci M96/1 AY683893 A. astaci Ho AY310500 A. astaci FDL457 AB510348 A. salsuginosus FM955258 Aphanomyces sp.

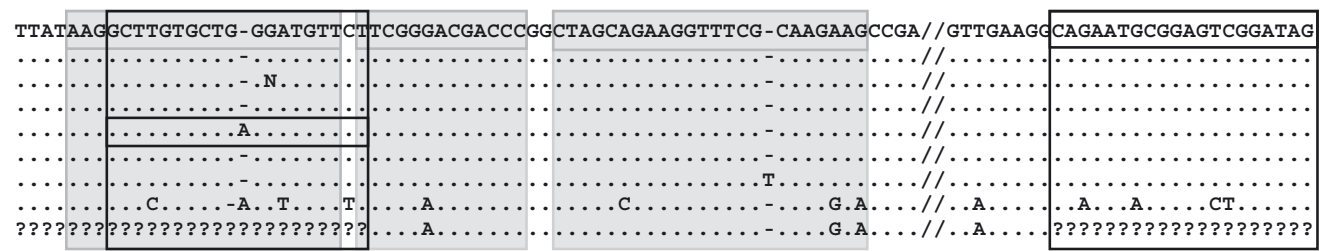

Fig. 4. Partial internal transcribed spacer sequence alignment reflecting the primer and probe sequence motifs of the real-time PCR (Vrålstad et al. 2009) and single-round conventional PCR (Oidtmann et al. 2006) assays for species-specific detection of Aphanomyces astaci. The solid gray boxes show the positions of the primers AphAstITS-39F and AphAstITS-97R, as well as the TaqMan MGB probe AphAstITS-60T. The open black boxes show the positions of the primers 42 and 640 . Note that the primer 42 includes an insertion (extra A) only present in the A. astaci isolate ML96/1. The alignment is based on publicly available A. astaci sequences along with the sequence of the recently described Aphanomyces salsuginosus (Takuma et al. 2010) and the sequence obtained from the false positive detected by the primer pair 42/640 (Aphanomyces sp., FM955258; Kozubíková et al. 2009). The true sequence for the false positive is unknown in the region of primers 42 and 640 (denoted with question marks), since the sequence was amplified with these primers. The sequence motifs of $A$. salsuginosus and the false positive Aphanomyces sp. are largely overlapping in the regions of the primer AphAstITS-97R and the probe AphAstITS-60T

Apart from the confirmed false positive discussed above, only 6 additional samples (1.3\%) were not reliably detected by the real-time PCR. Trace amounts of putative Aphanomyces astaci DNA were detected in 5 of those 6 samples (Agent Level A1; see Table 3). These may well represent false positives, taking the results above into account. Alternatively, they may reflect the phenomenon that the ITS target DNA copies are not evenly distributed in the DNA sample, as they occur in tandem rDNA repeats in the genome. If only a few such DNA strands are present in the original DNA extract, rapid depletion of the extract may occur, and only one or a few reactions will turn out to be positive. This will result in a positive/negative ratio corresponding to a probability of detection $<95 \%$, i.e. below LOD. Finally, the DNA samples in the present study had been stored for some years after DNA extraction, and the target DNA may have been partially degraded. Hence, it cannot be excluded that the 5 samples in question originally contained true traces of $A$. astaci DNA. Whatever the reason may be, it is important to maintain the A1 category in the real-time PCR procedure as uncertain and unreliable, as suggested by Vrålstad et al. (2009), since true traces of $A$. astaci DNA and false positive signals may well overlap within this category.

We detected new positives by real-time PCR only in the samples containing DNA levels around or below the LOD of the semi-nested PCR (Oidtmann et al. 2006). This assay seems to work reliably when $>100$ PFU enters the PCR reaction, which is above Agent Level A2. The semi-nested PCR can still detect the agent DNA in the A2 category, but not with $100 \%$ efficiency (Table 3), which agrees well with the validation tests of Tuffs \& Oidtmann (2011). Our quanti- tative results demonstrate that PCR inhibition only marginally influenced the real-time detection of Aphanomyces astaci. Since the same DNA samples were used for the semi-nested PCR, inhibition is not a likely explanation for the lower sensitivity observed. Primer 42 of the semi-nested PCR (Oidtmann et al. 2006) includes an ' $A$ ' insertion at Position 11 that is missing in publicly available sequences of $A$. astaci strains other than M96/1 (AY310499), suggesting a sequencing error or intraspecific variation in Strain M96/1 (see Fig. 4). However, no difference in sensitivity was observed when a primer (42v2) without this mismatch was tested (Tuffs \& Oidtmann 2011), suggesting that the mismatch in primer 42 does not negatively influence assay sensitivity. More surprisingly, removing this mismatch had a drastic influence on assay specificity, and was therefore not recommended by Tuffs \& Oidtmann (2011). Hence, the observed difference in sensitivity between conventional PCR and real-time PCR observed in the present study and by Tuffs \& Oidtmann (2011) is more likely explained by technological and fragment size differences. More DNA is required to visualise a PCR band on a conventional agarose gel compared to detection by real-time PCR where just a few copies generate a signal. Further, the real-time and singleround conventional PCR assays target $57 \mathrm{bp}$ and 569 $\mathrm{bp}$, respectively. The detection ability of the conventional PCR assay is therefore more vulnerable to DNA degradation.

The observation that 16 and $32 \%$ of the spinycheek crayfish and signal crayfish, respectively, fell into Agent Level A1 may indicate that an even larger proportion of crayfish individuals in the present study were carriers of Aphanomyces astaci. Only soft 
abdominal cuticle was analysed in the present study, while additional analyses of the tail fan (including telson) or walking leg joints (Oidtmann et al. 2006, Strand et al. 2011) could have increased the observed number of carriers. Vrålstad et al. (2011) demonstrated significantly higher success of detecting $A$. astaci from tail fan tissues than from soft abdominal cuticle in signal crayfish, and recommended the use of tail fan tissue for A. astaci prevalence studies in that species.

The positive samples new to the current study occurred predominantly in signal crayfish from the Czech Republic (Table 2), and increased the frequency of Aphanomyces astaci positives from 1\% (Kozubíková et al. 2009) to $22 \%$ of all the tested signal crayfish from this country. Further, at least one $A$. astaci-carrying individual in all investigated Czech signal crayfish populations was uncovered. Similarly, we detected Agent Level A2 in 1 out of 2 investigated signal crayfish individuals from Slovakia. Invasions of American crayfish species were only recently reported from that country (Janský \& Kautman 2007, Petrusek \& Petrusková 2007), and, although the presence of the crayfish plague pathogen could be suspected, our analysis is the first to support this assumption with molecular data.

Intriguingly, 2 signal crayfish with very low agent levels (A2) were found even in a population where noble crayfish and signal crayfish had coexisted for at least $10 \mathrm{yr}$ without any sign of crayfish plague outbreak (locality Ráček II). We cannot rule out the presence of an avirulent $A$. astaci strain, or, alternatively, a false positive result due to cryptic Aphanomyces species diversity or minor laboratory-induced contamination. However, the results could also imply that crayfish plague outbreaks may be delayed for years in localities where European and American crayfish coexist, if the level of $A$. astaci infection in the carrier population is very low. Skov et al. (2011) recently reported that among 60 individuals from a mixed population of signal crayfish and noble crayfish in Denmark, no $A$. astaci-positive individuals were detected with the real-time PCR method of Vrålstad et al. (2009). Skov et al. (2011) acknowledged that it is impossible to declare a signal crayfish population free of infection, but assumed that the investigated signal crayfish population posed a minor, if any, threat for disease transmission. The present study underlines that extreme caution must be exercised before any American crayfish population is reported free of A. astaci infection. Sampling effort and diagnostic procedures will influence the probability of detecting $A$. astaci in populations with very low agent prevalence. If future studies confirm that even mixed populations of American and European crayfish may represent minor infection reservoirs of $A$. astaci, it may be only a matter of time before the conditions allow the crayfish plague to strike, leaving the coexisting indigenous European crayfish at constant risk.

Our semi-quantitative data for a large set of American crayfish samples are in concordance with the findings of Vrålstad et al. (2009) where most positive samples of American crayfish showed agent levels between A2 and A3. However, our spiny-cheek crayfish samples sometimes contained higher levels of pathogen DNA (A4 or A5). Such levels correspond to those found in noble crayfish that had suffered mortality from crayfish plague (Vrålstad et al. 2009). We also found a positive correlation between the prevalence of Aphanomyces astaci-positive individuals in American crayfish populations and the agent levels for each individual. This is presumably due to increased numbers of $A$. astaci zoospores in environments with higher $A$. astaci prevalence, which, in turn, increases infection probability.

The high sensitivity of the real-time PCR method shows that the previous results of Aphanomyces astaci detection based on conventional PCR have suffered from false negatives. However, the extreme sensitivity of real-time PCR is a challenge concerning laboratory contamination and requires excellent laboratory practices. Further, false positives are not revealed unless sequenced, and putative new strains of A. astaci may fail to be detected by real-time PCR alone. To avoid these pitfalls, conventional PCR allowing sequencing should be performed in parallel with real-time PCR when appropriate. The present study demonstrates that this combination is beneficial and may uncover erroneous results and increase our understanding of the pathogen distribution patterns.

Acknowledgements. The present study was funded by the Grant Agency of the Charles University (Project No. 154110), the Czech Science Foundation (206/08/H049), the Czech Ministry of Education (MSM0021620828), and the French National Agency for Water and Aquatic Environments (ONEMA). We thank B. Oidtmann and anonymous reviewers for valuable comments on a previous version of the manuscript.

\section{LITERATURE CITED}

Aquiloni L, Martín MP, Gherardi F, Diéguez-Uribeondo J (2011) The North American crayfish Procambarus clarkii is the carrier of the oomycete Aphanomyces astaci in Italy. Biol Invasions 13:359-367 
Ballesteros I, Martín MP, Diéguez-Uribeondo J (2006) First isolation of Aphanomyces frigidophilus (Saprolegniales) in Europe. Mycotaxon 95:335-340

Diéguez-Uribeondo J, García MA, Cerenius L, Kozubíková E and others (2009) Phylogenetic relationships among plant and animal parasites, and saprotrophs in Aphanomyces (Oomycetes). Fungal Genet Biol 46: 365-376

Hochwimmer G, Tober R, Bibars-Reiter R, Licek E, Steinborn R (2009) Identification of two GH18 chitinase family genes and their use as targets for detection of the crayfish-plague oomycete Aphanomyces astaci. BMC Microbiol 9:184

Holdich DM, Reynolds JD, Souty-Grosset C, Sibley PJ (2009) A review of the ever increasing threat to European crayfish from non-indigenous crayfish species. Knowl Manag Aquat Ecosys 394-395:11

Janský V, Kautman J (2007) Americký rak Orconectes limosus (Crustacea: Decapoda: Cambaridae) už aj na Slovensku. [North American spiny-cheek crayfish Orconectes limosus (Crustacea: Decapoda: Cambaridae) also in Slovakia.]. Acta Rerum Nat Mus Natl Slov Bratisl 53:21-25 (in Slovak with English Abstract)

Kozubíková E, Petrusek A, Ďuriš Z, Kozák P, Geiger S, Hoffmann R, Oidtmann B (2006) The crayfish plague in the Czech Republic-review of recent suspect cases and a pilot detection study. Bull Fr Peche Piscicult 380-381: 1313-1324

Kozubíková E, Petrusek A, Duriš Z, Martín MP, DiéguezUribeondo J, Oidtmann B (2008) The old menace is back: recent crayfish plague outbreaks in the Czech Republic. Aquaculture 274:208-217

Kozubíková E, Filipová L, Kozák P, Duriš Z and others (2009) Prevalence of the crayfish plague pathogen Aphanomyces astaci in invasive American crayfishes in the Czech Republic. Conserv Biol 23:1204-1213

Kozubíková E, Puky M, Kiszely P, Petrusek A (2010) Crayfish plague pathogen in invasive North American crayfish species in Hungary. J Fish Dis 33:925-929

Makkonen J, Jussila J, Henttonen P, Kokko H (2011) Genetic variation in the ribosomal internal transcribed spacers of Aphanomyces astaci Schikora from Finland. Aquaculture 311:48-53

Oidtmann B, Cerenius L, Schmid I, Hoffmann R, Söderhäll K (1999) Crayfish plague epizootics in Germany-classification of two German isolates of the crayfish plague fungus Aphanomyces astaci by random amplification of polymorphic DNA. Dis Aquat Org 35:235-238

Oidtmann B, Schaefers N, Cerenius L, Söderhäll K, Hoffmann RW (2004) Detection of genomic DNA of the cray- fish plague fungus Aphanomyces astaci (Oomycete) in clinical samples by PCR. Vet Microbiol 100:269-282

> Oidtmann B, Geiger S, Steinbauer P, Culas A, Hoffmann RW (2006) Detection of Aphanomyces astaci in North American crayfish by polymerase chain reaction. Dis Aquat Org 72:53-64

OIE (World Organisation for Animal Health) (2010) Crayfish plague (Aphanomyces astaci). Manual of diagnostic tests for aquatic animals, Chapter 2.2.1. OIE, Paris. Available at: www.oie.int/fileadmin/Home/eng/Health_ standards/aahm/2010/2.2.01_CRAYFISH.pdf (accessed on 11 Nov 2011)

> Petrusek A, Petrusková T (2007) Invasive American crayfish Pacifastacus leniusculus (Decapoda: Astacidae) in the Morava River (Slovakia). Biologia 62:356-359

Schulz HK, Smietana P, Maiwald T, Oidtmann B, Schulz R (2006) Case studies on the co-occurrence of Astacus astacus (L.) and Orconectes limosus (Raf.): snapshots of a slow displacement. Freshw Crayfish 15:212-219

> Skov C, Aarestrup K, Sivebæk F, Pedersen S, Vrålstad T, Berg S (2011) Non-indigenous signal crayfish Pacifastacus leniusculus are now common in Danish streams: preliminary status for national distribution and protective actions. Biol Invasions 13:1269-1274

Strand DA, Holst-Jensen A, Viljugrein H, Edvardsen B, Klaveness D, Jussila J, Vrålstad T (2011) Detection and quantification of the crayfish plague agent in natural waters - an approach for direct monitoring of aquatic environments. Dis Aquat Org 95:9-17

Takuma D, Sano A, Wada S, Kurata O, Hatai K (2010) A new species, Aphanomyces salsuginosus sp. nov., isolated from ice fish Salangichthys microdon. Mycoscience 51: 432-442

Tuffs S, Oidtmann B (2011) A comparative study of molecular diagnostic methods designed to detect the crayfish plague pathogen, Aphanomyces astaci. Vet Microbiol 153:343-353

> Vrålstad T, Knutsen AK, Tengs T, Holst-Jensen A (2009) A quantitative TaqMan MGB real-time polymerase chain reaction based assay for detection of the causative agent of crayfish plague Aphanomyces astaci. Vet Microbiol 137:146-155

> Vrålstad T, Johnsen SI, Fristad R, Edsmann L, Strand D (2011) Potent infection reservoir of crayfish plague now permanently established in Norway. Dis Aquat Org 97: 75-83

Yao Y, Nellåker C, Karlsson H (2006) Evaluation of minor groove binding probe and TaqMan probe PCR assays: influence of mismatches and template complexity on quantification. Mol Cell Probes 20:311-316 
Appendix 1. Table A1. Overview of DNA isolates in which Aphanomyces astaci was detected above the limit of quantification $(\mathrm{LOQ}=50$ PCR-forming units [PFU]). Origin indicates crayfish species (Olim: Orconectes limosus; Plen: Pacifastacus leniusculus) and country (CZ: Czech Republic; H: Hungary). Acceptable quantification (AQ): the difference in cycle threshold values $(\Delta \mathrm{Ct})$ between the 10 -fold diluted and the undiluted DNA replicate is $3.32( \pm 0.5)$. Here, the given PFU-value per sample is calculated as the means of the PFU-value of undiluted DNA and the PFU-value of 10 -fold diluted DNA multiplied by 10 . A $\Delta$ Ct $<$ 2.82 indicates minor inhibition ( $\mathrm{MI}$; data in bold). The PFU-value in these cases is not accurate, but based on the 10-fold diluted PFU estimate (multiplied by 10). A $\Delta \mathrm{Ct}>3.82$ indicates that the 10 -fold dilution is out of range (OR; data in italics). The PFU-value is uncertain and solely based on the undiluted DNA sample

\begin{tabular}{|c|c|c|c|c|c|c|c|c|c|c|c|}
\hline Origin & Sample & $\begin{array}{l}\text { Agent } \\
\text { level }\end{array}$ & $\Delta \mathrm{Ct}$ & $\mathrm{PFU}$ & $\begin{array}{l}\text { Quantitative } \\
\text { evaluation }\end{array}$ & Origin & Sample & $\begin{array}{c}\text { Agent } \\
\text { level }\end{array}$ & $\Delta \mathrm{Ct}$ & PFU & $\begin{array}{c}\text { Quantitative } \\
\text { evaluation }\end{array}$ \\
\hline Olim-CZ & SME12 & A5 & 3.47 & 45695 & $A Q$ & Olim-CZ & SME13 & A3 & 3.18 & 208 & $\mathrm{AQ}$ \\
\hline Olim-CZ & SME37 & A4 & 3.68 & 8297 & $\mathrm{AQ}$ & Olim-CZ & SME25 & A3 & 3.56 & 186 & $\mathrm{AQ}$ \\
\hline Olim-CZ & SME36 & $\mathrm{A} 4$ & 3.55 & 6611 & $\mathrm{AQ}$ & Olim-CZ & JIC12 & A3 & 3.79 & 181 & $\mathrm{AQ}$ \\
\hline Olim-CZ & SME17 & $\mathrm{A} 4$ & 3.38 & 4623 & $A Q$ & Olim-CZ & SME18 & A3 & 2.8 & 175 & MI \\
\hline Olim-CZ & KOR1 & $\mathrm{A} 4$ & 3.72 & 2420 & $A Q$ & Olim-CZ & JIC11 & A3 & 3.09 & 162 & $\mathrm{AQ}$ \\
\hline Olim-CZ & SME9 & A4 & 4.01 & 2406 & $O R$ & Olim-CZ & PRU1 & A3 & 3.38 & 162 & $\mathrm{AQ}$ \\
\hline Olim-CZ & KOR2 & $\mathrm{A} 4$ & 3.74 & 2218 & $A Q$ & Olim-CZ & SME29 & A3 & 2.86 & 160 & $\mathrm{AQ}$ \\
\hline Olim-CZ & LAB6 & $\mathrm{A} 4$ & 3.82 & 2116 & $A Q$ & Olim-CZ & PRU3 & A3 & 4.38 & 151 & $O R$ \\
\hline Olim-CZ & SME21 & $\mathrm{A} 4$ & 3.67 & 2001 & $A Q$ & Olim-CZ & PRU10 & A3 & 4.82 & 137 & $O R$ \\
\hline Olim-CZ & SME27 & A4 & 3.23 & 1853 & $A Q$ & Olim-CZ & SME16 & A3 & 2.85 & 135 & $\mathrm{AQ}$ \\
\hline Olim-CZ & SME7 & $\mathrm{A} 4$ & 3.6 & 1807 & $A Q$ & Olim-CZ & SME40 & A3 & 3.48 & 130 & $\mathrm{AQ}$ \\
\hline Olim-CZ & SME11 & $\mathrm{A} 4$ & 3.34 & 1476 & $A Q$ & Olim-CZ & JIC8 & A3 & 4.46 & 129 & $O R$ \\
\hline Olim-CZ & SME35 & $\mathrm{A} 4$ & 3.72 & 1432 & $A Q$ & Olim-CZ & SME20 & A3 & 3.31 & 123 & $\mathrm{AQ}$ \\
\hline Olim-CZ & PRU11 & $\mathrm{A} 4$ & 3.83 & 1330 & $O R$ & Olim-CZ & SME22 & A3 & 3.3 & 119 & $\mathrm{AQ}$ \\
\hline Olim-CZ & JIC14 & A4 & 3.54 & 1213 & $\mathrm{AQ}$ & Olim-CZ & JIC13 & A3 & 4.39 & 108 & $O R$ \\
\hline Olim-CZ & SME15 & $\mathrm{A} 4$ & 3.52 & 1028 & $\mathrm{AQ}$ & Olim-CZ & SME2 & A3 & 4.27 & 108 & $O R$ \\
\hline Olim-CZ & SME10 & A3 & 3.38 & 901 & $A Q$ & Olim-CZ & SME33 & A3 & 3.27 & 99 & $\mathrm{AQ}$ \\
\hline Olim-CZ & SME8 & A3 & 3.45 & 846 & $A Q$ & Olim-CZ & PSO12 & A3 & 2.71 & 95 & MI \\
\hline Olim-CZ & LAB3 & A3 & 3.42 & 710 & $A Q$ & Olim-CZ & PSO18 & A3 & 3.4 & 93 & $\mathrm{AQ}$ \\
\hline Olim-CZ & JIC3 & A3 & 3.54 & 703 & $A Q$ & Olim-CZ & PSO2 & A3 & 5.55 & 91 & $O R$ \\
\hline Olim-CZ & PRU6 & A3 & 4.02 & 629 & $O R$ & Olim-CZ & PRU8 & A3 & 5.23 & 86 & $O R$ \\
\hline Olim-CZ & JIC15 & A3 & 3.93 & 572 & $O R$ & Olim-CZ & PRU2 & A3 & 3.73 & 85 & $\mathrm{AQ}$ \\
\hline Olim-CZ & SME26 & A3 & 3.03 & 538 & $\mathrm{AQ}$ & Olim-CZ & SME31 & A3 & 4.2 & 85 & $O R$ \\
\hline Olim-CZ & PRU7 & A3 & 3.61 & 504 & $\mathrm{AQ}$ & Olim-CZ & PRU4 & A3 & 3.74 & 83 & $\mathrm{AQ}$ \\
\hline Olim-CZ & SME30 & A3 & 3.36 & 452 & $\mathrm{AQ}$ & Olim-CZ & MAL5 & A3 & 4.23 & 79 & $O R$ \\
\hline Olim-CZ & SME19 & A3 & 3.21 & 434 & $\mathrm{AQ}$ & Olim-CZ & JIC10 & A3 & 3.18 & 78 & $\mathrm{AQ}$ \\
\hline Olim-CZ & SME34 & A3 & 3.41 & 406 & $A Q$ & Olim-CZ & JIC7 & A3 & 3.71 & 76 & $\mathrm{AQ}$ \\
\hline Olim-CZ & SME5 & A3 & 3.47 & 390 & $A Q$ & Olim-CZ & JIC6 & A3 & 3.65 & 75 & $\mathrm{AQ}$ \\
\hline Olim-CZ & JIC4 & A3 & 3.68 & 365 & $A Q$ & Olim-CZ & PRO08 & A3 & 3.58 & 73 & $\mathrm{AQ}$ \\
\hline Olim-CZ & DEC3 & A3 & 3.31 & 336 & $A Q$ & Olim-CZ & LAB5 & A3 & 4.36 & 62 & $O R$ \\
\hline Olim-CZ & PRU5 & A3 & 3.39 & 328 & $A Q$ & Olim-CZ & PSO5 & A3 & 3.34 & 61 & $\mathrm{AQ}$ \\
\hline Olim-CZ & SME6 & A3 & 3.67 & 296 & $A Q$ & Olim-CZ & PSO11 & A3 & 3.57 & 58 & $\mathrm{AQ}$ \\
\hline Olim-CZ & PSO9 & A3 & 2.78 & 294 & MI & Olim-CZ & MAL6 & A3 & 3.96 & 53 & $O R$ \\
\hline Olim-CZ & LAB2 & A3 & 3.64 & 282 & $A Q$ & Olim-H & G1 & A3 & 4.19 & 238 & $O R$ \\
\hline Olim-CZ & SME4 & A3 & 3.24 & 281 & $A Q$ & Plen-CZ & NAD47 & A3 & 2.89 & 96 & $\mathrm{AQ}$ \\
\hline Olim-CZ & SME3 & A3 & 3.28 & 263 & $A Q$ & Plen-CZ & NAD12 & A3 & 6.45 & 87 & $O R$ \\
\hline Olim-CZ & FAR2 & A3 & 5.09 & 253 & $O R$ & Plen-CZ & NAD16 & A3 & 6.8 & 68 & $O R$ \\
\hline Olim-CZ & JIC5 & A3 & 4.05 & 247 & $O R$ & Plen-H & HRI14 & A3 & 3.55 & 57 & $\mathrm{AQ}$ \\
\hline Olim-CZ & PRU9 & A3 & 3.7 & 239 & $A Q$ & Plen-H & HRI3 & A3 & 4.32 & 51 & $O R$ \\
\hline Olim-CZ & JIC9 & A3 & 3.84 & 228 & $O R$ & & & & & & \\
\hline
\end{tabular}

Editorial responsibility: Grant Stentiford, Weymouth, UK
Submitted: February 1, 2011; Accepted: September 5, 2011 Proofs received from author(s): November 15, 2011 